\title{
MANAGING HIGH-QUALITY HUMAN RESOURCES IN VIETNAMESE SMALL AND MEDIUM ENTERPRISES
}

\author{
Nguyen QuangHuy, Pham My Quyen \\ Department of Economic Transportation, University of Transport and Communications, \\ Vietnam
}

DOI $<10.26821 / \mathrm{IJSRC} .8 .3 .2020 .8307>$

\begin{abstract}
Vietnamese small and medium enterprises account for $98 \%$ of the total number of enterprises in the country; over the past time, the small and medium enterprise sector has contributed significantly to the development of Vietnam's economy (Ministry of Planning and Investment, 2019). However, the competitiveness of this business sector is still very limited, mainly because the capacity and qualifications of managers are weak, especially the quality of human resources. This paper focuses on the situation of high-quality human resources in small and medium enterprises in Ho Chi Minh City; the difficulties in attracting high-quality human resources; at the same time, propose solutions to attract high-quality human resources in small and medium enterprises in Ho Chi Minh City.
\end{abstract}

Keywords: Human resources, high-quality, small and medium enterprises, Vietnam, Ho Chi Minh City

\section{INTRODUCTION}

Human resources are the most valuable resource of all other resources of the enterprise, which is the basic factor determining the development and success of enterprises (De Vroey, Michel; Malgrange, Pierre, 2012). How to help small and medium-sized enterprises improve the quality of human resources, particularly the recruitment and efficient use of human resources, is a matter of great concern to businesses. Many businesses have suffered as a result of inexperience building and maintaining a rigorous and scientific human resource evaluation and development system. In some places, the dissatisfied key official quits his job and his subordinates are bewildered. In other places, customers are lost due to deteriorating service quality, defective products increase costs, my power at the highest level (Szenberg, Michael; Gottesman, Aron A.; Ramrattan, Lall., 2005). People who are rated correctly will be pleased to be recognized. They will work harder, increase labor productivity, and reduce costs. Besides, on the business side, once having evaluated the right people, it will greatly reduce the time and money in training employees.

Ho Chi Minh City is the economic, cultural and socio-political center of the country, which has great potentials in industry, trade, services, import and export, etc; however, at present, it has not developed its potential. Small and medium enterprises in Ho Chi Minh City still have low competitiveness and economic efficiency, which are not commensurate with the 
Volume 8 Issue 3 March 2020

position and potential of the most dynamic city in the country. Therefore, how do small and medium enterprises in Ho Chi Minh City exist and develop steadily, contributing more to the development of the city in particular and the economy of the whole country? It is an urgent, important and practical issue that needs thorough consideration and resolution.

\section{SOME CONCEPTS}

\subsection{Human Resources}

The term human resources were first coined in the 1960s when the value of labor relations began to garner attention and when notions such as motivation, organizational behavior, and selection assessments began to take shape. William R. Tracey (2016), in "The Human Resources Glossary," defines Human Resources as: "The people that staff and operate an organization," as contrasted with the financial and material resources of an organization.

A human resource is a single person or employee within your organization. Human resources refer to all of the people you employ.

Human Resources is also the function in an organization that deals with the people and issues related to people such as compensation and benefits, recruiting and hiring employees, onboarding employees, performance management, training, and organization development and culture.

So, human resources are used to describe both the people who work for a company or organization and the department responsible for managing resources related to employees. Human Resources staff is also responsible for advising senior staff about the impact on people (the human resources) of their financial, planning, and performance decisions. Managers rarely discuss the effect of their decisions on the people in the organizations. It is often predictable that decisions are driven by more easily measurable processes such as finance and accounting.

\subsection{High Quality Human Resources}

Recent research documents show that the authors when approaching the concept of high quality human resources are inclined to view and point out the criteria to identify high quality human resources.

There are many workshops, writing pages giving insights on high quality human resources. For example: "High-quality human resources in the period of industrialization and modernization are the contingent of leaders and managers; scientific and technological human resources - those who have university or higher education and a group of high-quality technical workers "(Hai Phong City, Workshop on the project of high-quality human resources, 2008). High quality human resources "includes those with university and college degrees; human resources for leadership in management and policy making, science and technology human resources, lecturers at universities and colleges "(Industry Magazine, Workshop on the situation and solutions for developing human resources high quality force, 2008)

Thus, high quality human resources must be considered on all aspects of the quality of human resources: physical, intellectual and mental. As seen, the assessment of human resources is a high quality human resource or not, it is a comprehensive assessment on all aspects. Guaranteed in association with labor results. 
The development of labor division is closely related to the development process of science and technology. Since then, the formation of different human resources follows the development trend of social labor division.

In short, high-quality human resources is the concept of specific workers who have good professional skills (in terms of professional and technical skills) for a specific job, according to the criteria of professional labor classification. certain subjects and techniques (undergraduate, postgraduate, skilled technical labor); good labor skills and the ability to quickly adapt to the rapid changes of production and business technology; have good health and qualities; be able to creatively apply the knowledge and skills that have been trained in the production labor process to bring about labor productivity, quality and high efficiency.

\section{THE SITUATION OF HIGH-QUALITY HUMAN RESOURCES IN HO CHI MINH CITY}

Developing high-quality human resources is one of the 7 breakthrough programs of Ho Chi Minh City until 2030. However, the reality of human resources in Ho Chi Minh City is currently large in number but not stable stability and sustainability.

According to Ho Chi Minh City Manpower Forecasting and Labor Market Information Center (2019), the city's labor market is developing with the requirement to quickly increase highly qualified and knowledgeable human resources skills in science, technology, management, production, and business.

However, the labor market has not developed comprehensively, showing the difference between labor supply and demand in terms of quantity; Especially, the quality is not consistent with the requirements of economic development and integration. Ho Chi Minh City is abundant in unskilled labor but lacks highly qualified human resources for the development-oriented industries.

The center surveyed the recruitment needs of businesses in the city in 2019, the results showed that Ho Chi Minh City is expected to recruit 300,000 employees, an average increase of 5\% compared to 2017. About structure and labor with the university degree or above $20 \%$; college $17 \%$; intermediate and skillful technology $32 \%$; primary vocational training $10 \%$ and unskilled labor $21 \%$.

Employment opportunities in Ho Chi Minh City in 2020 will be open for highly skilled, skilled workers, equipped with soft skills, especially communication and teamwork skills, discipline, ethics. Career, labor responsibility, informatics, and foreign-language application capacity.

Therefore, by 2020, the city's labor market will focus on attracting high-quality human resources to work in key industries and fields; attaching importance to developing according to the trend of trained and skilled laborers who require the quality, labor skills, skills, and labor productivity to ensure the expansion of production and business scale, beginning of foreign investment, labor export, etc. Meanwhile, the majority of graduates do not have enough professional skills, foreign language skills, soft skills to access jobs, especially the skills that the labor market needs (Ho Chi Minh City Manpower Forecasting and Labor Market Information Center, 2019) 
Experts said that (Samsung, Toyota, LG, IBM, 2017), the quality of human resources is an important factor affecting the change in labor productivity. In fact, in terms of training level, the group with intermediate training level (college, vocational secondary) has the strongest impact on labor productivity but Vietnam is lacking this human resource. The number of middle-class workers currently only meets $20-30 \%$ of labor demand (Ho Chi Minh City Manpower Forecasting and Labor Market Information Center, 2019)

In addition, the economy also occurs the unreasonable use of human resources, the rate of under-use of professional and technical qualifications is from 16-24\% (Ho Chi Minh City Manpower Forecasting and Labor Market Information Center, 2019). The reason is that the training of high and middle-class human resources is still weak; policies on training and developing human resources have not been based on market requirements and have not created conditions for labor transition; student channeling, human resource forecasts are not close to human needs in each field.

Professor - Dr. Vu Dinh Thanh, Rector of Ho Chi Minh City University of Technology (2019) assessed: Currently there are many training schools, there are many training projects but in general, human resources are high quality. High quality is still lacking. High-quality human resources not only in tertiary education but also in college and yocational training.

We train a lot but do not have training stratification, so the domestic training units are similarly trained, leading to a large number of graduates but not used (Ho Chi Minh City Manpower Forecasting and Labor Market Information Center, 2019). In addition, universities that train engineers and technical experts do not mean that the right training of a person does the right thing but requires background knowledge training. When entering the enterprise, employees are required to receive additional professional knowledge or time to learn.

\section{THE SITUATION OF HUMAN RESOURCE MANAGEMENT IN SMALL AND MEDIUM ENTERPRISES IN HO CHI MINH CITY}

\subsection{Regarding Human Resource Planning}

Small and medium enterprises are the type of enterprises that dominate and play an important role in creating jobs as well as increasing incomes for workers, helping to mobilize social resources for development investment and hunger eradication. Poverty reduction, etc. Every year, these businesses create more than 500,000 employees, employ up to 50\% of social labor and contribute more than $40 \%$ of the country's GDP (General Statistics Office of Vietnam, 2019).

Owners of small and medium-sized businesses are usually engineers or technicians who set up and run the business themselves, they are both managers and directly involved in the production, so the level of expertise in business management the karma is not high. In addition, most small and medium-sized business owners do not participate in formal management training courses and do not have sufficient knowledge on corporate governance; Only manage according to experience and subjective opinion.

Currently, very few small and medium-sized enterprises are planning long-term human resources (Ho Chi Minh City Manpower Forecasting and Labor Market Information Center, 2019). According to statistics (Department of Planning and Investment of Ho Chi Minh City, 2019), up to $85 \%$ of total businesses make demand forecasts based on the number of employees 
Volume 8 Issue 3 March 2020

that need to be replaced, only about $15 \%$ is based on changes in science, technology, demand for products and services, capital size, etc. In addition, the determination of excess or shortage of labor is only determined by each department based on the block amount of current work without the involvement of the human resources department. The HR department only functions to receive labor quotas and perform recruitment.

Many small and medium business owners in Ho Chi Minh City only identify the need for human resources in the short term or even based on the current time to make decisions. Only enterprises with 50-300 employees are still interested and devising human resources strategies, but these strategies are still very sketchy (Department of Planning and Investment of Ho Chi Minh City, 2019).

Regarding the assessment of the implementation of the human resource plan and the projection of the plan for the following year, the managers of Vietnamese small and medium enterprises in general and enterprises Small and medium-sized people in particular still do not attach much importance to this process, so the work of planning human resources, especially high-quality human resources, is still very simple.

\subsection{About Recruiting Personnel}

For internal recruiting sources: when the recruitment is conducted, the organizationadministration department will notify the system units and other professional departments, each department will consider individuals those who are capable of taking charge of the work shall notify the organization office. However, because human resources in small and medium enterprises are often small in scale, the advantage of internal recruitment is not much. According to the Association of Small and Medium Enterprises in Ho Chi Minh City (2019), this activity takes place very little and often does not attract good people to apply.

For recruiting from outside: recruitment through job introduction organizations is still very modest (Ho Chi Minh City Association of Small and Medium Enterprises, 2019). Human resources from training institutions and the mass media are part of the guarantee for businesses to recruit the right people and the right jobs. This form is mainly applied to enterprises with 50 employees or more, including recruitment notices via the Internet, newspapers, Facebook, Zalo, etc. According to statistics, $25 \%$ of businesses recruit through the mass media, the ratio which is very low compared to similar developed cities in the region and in the world (Ho Chi Minh City Association of Small and Medium Enterprises, 2019).

Each enterprise chooses a specific recruitment method, but most small and mediumsized enterprises in Ho Chi Minh City carry out the following steps of the recruitment process: receiving applications and researching; select qualified candidates for interview (direct questions for candidates to answer (Ho Chi Minh City Association of Small and Medium Enterprises, 2019), answer questionnaires, check IQ test, etc.

When conducting the interview, the interviewing enterprises consisted of the director, the head of the human resources department and the personnel staff interviewed. Candidates who pass the interview will be admitted to probation within 3-6 months, after which the enterprise will sign a formal contract. However, during this time, many workers quit their jobs and found a new job position for many reasons, including remuneration policies, salaries, 
transportation, etc. These are the most impacting factors (Ho Chi Minh City Association of Small and Medium Enterprises, 2019).

In fact, many small and medium enterprises in Ho Chi Minh City due to low awareness and management, so after the recruitment process, these enterprises often end the recruitment process. No matter what the hiring effect is, will you reach the goals of the hiring process, etc? Therefore, the task of evaluating the effectiveness of the selection process is only conducted by about 35\% of small and medium-sized enterprises (Ho Chi Minh City Association of Small and Medium Enterprises, 2019).

\subsection{Regarding Training, Improving Skills for employees}

According to the Ho Chi Minh City Association of Small and Medium Enterprises (2019), most small and medium-sized enterprises do not have a training and development strategy associated with their specific vision and goals. Another fact is that many businesses in Ho Chi Minh City are only interested in training senior managers and experts. As for the training of technical experts and workers, the main form of training is self-training or workers have to improve their own skills.

In addition to the above-mentioned weaknesses in corporate governance, many of the small and medium-sized enterprises in Ho Chi Minh City have not yet built a complete payroll regime for employees (Ho Chi Minh City Association of Small and Medium Enterprises, 2019). The method of payment is mainly based on working time, specifically, employees will have to work eight hours a day. With this form of payment, employees will be limited to creativity, laziness, et. do not encourage workers to work, creating high surplus value for businesses.

From the aforementioned situation, it can be seen that the efficiency of the use and management of internal human resources, especially high-quality human resources in Ho Chi Minh City, is still quite low, failing to meet the development situation develop rapidly of the city economy in particular and of Vietnam in general, as well as current human resource requirements. Human resource management in these enterprises is not interested in developing, so it cannot take full advantage of labor resources in the enterprise.

\section{SOLUTIONS TO IMPROVE HIGH-QUALITY HUMAN RESOURCE MANAGEMENT IN SMALL AND MEDIUM ENTERPRISES IN HO CHI MINH CITY.}

\subsection{Regarding Human Resource Planning}

Improving the analysis and planning of human resources. In order to conduct a reasonable human resource planning, businesses need to first properly view the current state of employee activities in an objective and specific way.

Small and medium-sized businesses need to conduct surveys about the workload of their employees as well as the ability to fulfill their tasks by developing evaluation sheets, or regular scorecards. This form should be applied monthly, employees will give their own points, and managers are not biased.

An enterprise wants to operate well, it needs to have a good quality human resource, in accordance with the actual requirements of the business. To be able to grasp that, businesses necessarily need to conduct human resource planning. 
Volume 8 Issue 3 March 2020

The human resources department should do well the work of managing personnel records to ensure the assignment is appropriate with the ability of employees to avoid the phenomenon of misplaced jobs that affect the performance work results. This is a very important principle in human resource management.

\subsection{Develop Policies to Attract Human Resources}

Develop insurance policies for employees. Small and medium-sized businesses often find it difficult to provide assurance for workers, so workers working in these businesses are often very worried by the risk of bankruptcy of the business. Therefore, it is necessary to take measures to strengthen and develop employment insurance policies, social insurance for workers. Specific measures include:

Increase the number of employees participating in compulsory social insurance, including employees in enterprises, businesses, and wage earners in all economic sectors in accordance with the Labor Code.

Study to promulgate voluntary social insurance policies. Voluntary social insurance is one of the forms for people to participate in social insurance. Unlike compulsory social insurance, subjects participating in voluntary social insurance are not constrained by the subjects specified in Article 2 of the Law on Social Insurance 2014. As long as there is demand, people in everyone from 15 years of age or older can participate and enjoy certain benefits as prescribed by law. This is a relatively difficult job because it relates to the rights of workers, so it needs to be done regularly and permanently.

\subsection{Improve the Quality of the Management Team}

Currently, the quality of the management team in Vietnamese small and medium enterprises has little experience in international business. Therefore, the improvement of the quality of the contingent of administrators is extremely urgent.

The Government and the small and medium enterprise development promotion agencies in Ho Chi Minh City need to organize workshops to propagate this issue to the administrators, to help them realize the importance of education, management experience and encourage them to study.

The management capacity of small and medium-sized business executives is still weak, mainly having only professional knowledge but not much management experience. Therefore, government agencies, local authorities, and small and medium-sized business support centers need to develop managers' training courses and call for and encourage administrators to participate.

\subsection{Perfecting the Recruitment of Personnel, Salary, and Remuneration}

Businesses should make recruitment from the university. Currently, businesses are not interested in joining in training human resources from universities but only know how to use human resources after training. If small and medium-sized businesses have a strategy to recruit student's right from the school, not only will businesses save money for complex recruitment later, but they can also recruit high-quality human resources. 
In the strong development trend of the economy of Vietnam in general and the economy of Ho Chi Minh City in particular, small and medium enterprises in the city are increasingly playing an important role in the economy. Small and medium enterprises increasingly create jobs, mobilize many capital sources from the population as well as contribute greatly to the GDP growth of the City and the whole country.

The bonuses also work to encourage the morale of employees and associate employees with businesses so businesses should not be rigid to apply the current salary of the State, but should consider evaluating the work, distribution. Analyze the work of each officer and review the salary in the market to have general criteria for salary distribution.

\section{CONCLUSION}

Small and medium enterprises play a very important role in stabilizing and developing socio-economic of Vietnam in general and of Ho Chi Minh City in particular. In the process of international economic integration, Vietnamese enterprises in general and especially small and medium enterprises - with their weaknesses, it is increasingly difficult to overcome many challenges to survive and develop.

Human resource development is an important solution to help small and medium enterprises fulfill development goals and overcome the challenges of economic integration. Implementing this solution requires great efforts of each business owner as well as the support of the State, Ho Chi Minh City, and internationalorganizations.

\section{REFERENCES}

Anh, L. (2019). Supporting businesses to improve their competitiveness and catch up with opportunities. Retrieved fromhttp://baochinhphu.vn/Doanh-nghiep/TPHCM-Ho-troDN-nang-cao-nang-luc-canh-tranh-don-dau-co-hoi/377247.vgp

Anh, T. N. (2017). Factors affecting competition capacity of Vietnam enterprises. Retrieved fromhttps://dangkykinhdoanh.gov.vn/vn/tin-tuc/603/3688/nhung-yeu-to-anh-huong-toinang-luc-canh-tranh-cua-doanh-nghiep-viet-nam.aspx

De Vroey, Michel; Malgrange, Pierre. (2012). "From the Keynesian revolution to the KleinGoldberger model: Klein and the Dynamization of Keynesian theory". History of Economic Ideas. 20 (2): 113-36.

Dung, K. (2005). Human resource management. Hanoi: Statistical.

Duy, B. (2019). Improve competitiveness for businesses in the digital economy. Retrieved from https://congthuong.vn/nang-cao-nang-luc-canh-tranh-cho-doanh-nghiep-trong-nenkinh-te-so-127344.html

General Statistics Office. (2017).Report on the results of economic surveys in 2018. Hanoi: Statistical.

General Statistics Office of Vietnam. (2017). Vietnam human resources report. Hanoi: Statistics

General Statistics Office of Vietnam. (2018). Vietnam human resources report. Hanoi: Statistics 
Volume 8 Issue 3 March 2020

General Statistics Office of Vietnam. (2019). Vietnam human resources report. Hanoi: Statistics

Hoi, NT., Thang, P. (2006). Science of governance. Hanoi: Statistical.

Phuc, DV., (2005). Human resource management of businesses. Hanoi: Science Technology.

Szenberg, Michael; Gottesman, Aron A.; Ramrattan, Lall. (2005).Paul Samuelson: On Being an Economist. New York: Jorge Pinto Books.

The Government of the Socialist Republic of Vietnam. (2018). Resolution No. 19/NQ-CP on the tasks and solutions to improve the business environment and enhance national competitiveness.

The Government of the Socialist Republic of Vietnam. (2019).Resolution No. O2/NQ-CP on continuing to perform key tasks and solutions to improve the business environment, enhance national competitiveness in 2019 and orientations to 2021.

William R. Tracey. (2016).The Human Resources Glossary. St: Lucie Press. 